\title{
Effects of LED treatment and plasma-activated water on the growth and quality of Panax ginseng sprouts during hydroponic cultivation
}

\author{
Seo-Young Jeon ${ }^{1}$, Jung-Min Sung ${ }^{1}$, Jong-Hyeok Roh ${ }^{2}$, Ki-Hyun Kwon ${ }^{1,2 *}$ \\ ${ }^{1}$ Food Convergence Research Division, Korea Food Research Institute, Wanju 55365, Korea \\ ${ }^{2}$ Digital Factory Project Group, Korea Food Research Institute, Wanju 55365, Korea

\section{LED 처리 및 플라즈마 방전수에 의한 담수경재배 새싹삼의 생육 및 품질에 미치는 영향} \\ 전서영 ${ }^{1} \cdot$ 성정민 $^{1} \cdot$ 노종혁 $^{2} \cdot$ 권기현 $^{1,2 *}$ \\ 1한국식품연구원 식품융합연구본부, ${ }^{2}$ 한국식품연구원 디지털팩토리사업단
}

\begin{abstract}
Panax ginseng sprouts have important medicinal properties and thus the optimization of growth conditions is an important research goal. The effects of LED treatment and plasma-activated water on the growth and quality of Panax ginseng sprouts (PGS) in hydroponic cultivation were evaluated. Using 1-year-old ginseng plants, light was applied 9-18 h for the CGS, TGS1, TGS2, and TGS3 groups and $24 \mathrm{~h}$ for TGS4. Plasma-activated water was used in all groups except CGS and TGS1, and fermentation nutrient solutions (NO) were added to TGS1, TGS3, and TGS4. The TGS4 group had a high total length and initial length on days 7 and 14. At 21 days, the growth of TGS1, TGS3, and TGS4 with NO nutrient solutions increased. The total decay rate (\%) was low (4.24-4.65\%) for TGS1, TGS2, and TGS3. Although the chlorophyll $a, b$, and total chlorophyll contents were significantly higher in TGS4 than in other groups $(\mathbf{p}<\mathbf{0 . 0 5})$, TGS3 tended to show higher carotenoid levels. Therefore, for the hydroponic cultivation of PGS, nutrient solutions and plasma-activated water influence growth, and the LED treatment duration influences growth and functional substances. During hydroponic cultivation, TGS4 conditions resulted in high growth, saponin contents, and radical scavenging activity, with excellent functionality. However, considering the high rate of root decay, further studies of the effects of different wavelengths and treatment durations (light and dark cycles) on growth are needed.
\end{abstract}

Keywords: Panax ginseng sprout, hydroponics, light-emitting diode (LED), plasma-activated water, functional components

서 론

인삼(Panax ginseng C. A. Meyer)은 오갈피나무과(Araliaceae) 의 속하는 다년생 초본류로 사포닌을 다량 함유하여 면역기 능 개선, 피로개선 등의 기능성을 가지고 있다(MDFS, 2020). 최근 인삼 뿌리보다 잎에 더 많은 사포닌을 함유하고 있다고
보고되고, 이는 항산화, 항노화, 항당뇨 및 심혈관계 질병 예 방 등 각종 생리 기능성이 우수하다고 보고되어 있다(Seong 등, 2019). 그러나, 인삼 재배 기간은 4-6년으로 길며, 연작이 불가능하여 재배 가능 면적이 점차 줄어드는 실정이다(Lee 등, 2020). 그에 비해 새싹삼(Panax ginseng sprout, PGS) 재 배는 모밭에서 24개월 미만 재배한 모종삼(묘삼)을 25-40일

*Corresponding author. E-mail : kkh@kfri.re.kr, Phone :+82-63-2196-9258, Fax : +82-63-219-9876

Received 07 July 2021; Revised 13 October 2021; Accepted 13 October 2021.

Copyright (c) The Korean Society of Food Preservation.

This is an Open Access article distributed under the terms of the Creative Commons Attribution Non-Commercial License (http://creativecommons.org/licenses/by-nc/4.0) which permits unrestricted non-commercial use, distribution, and reproduction in any medium, provided the original work is properly cited. 
정도 재배해 뿌리와 어린잎 전체를 수확하여 인삼에 비해 재 배 기간이 짧고 연작이 가능하다는 장점과 뿌리뿐 아니라 잎 까지 섭취하는 새싹삼은 진세노사이드 함량이 높다고 보고되 어 있다(Chang 등, 2020). 이러한 특성으로 잎까지 수확하기 위해 토경재배보다는 수경재배(hydroponics)를 활용한 새싹 삼 재배가 이루어지고 있다. 수경재배는 식물공장에서 주로 사용하는 방식으로 외부 조건의 영향을 받지 않고 농작물에 대해 통제된 일정 시설 내에서 빛, 온도, 습도, $\mathrm{CO}_{2}$ 농도, 배 양액 등 환경 조건을 조절한다(Seo 등, 2008). 이 중 밀폐형 식물생산시스템에서 작물 생육에 필요한 광원은 인공광원으 로 발광다이오드(light-emitting diode, LED)가 주목받고 있 다. $\mathrm{LED}$ 는 소형 광원으로 공간 활용이 용이하고 특정 파장 대 LED 조합으로 광질, 광도와 광주기의 형태로 다양한 광 조건 인위적으로 조절할 수 있어 많이 사용되고 있다(Lee 등, 2016). 담수경 재배환경은 순환식 수경재배로 배양액을 흘려 주며 산소를 공급해주는 방식으로 관리의 효율성이 높으나 양액으로 인한 부영양화 및 미생물 증식으로 뿌리가 짓무르 고 썩는 집단 감염의 위험성이 있다. 이런 문제점을 감소시키 기 위해 플라즈마 처리가 살균에 효과가 있다고 보고된다. 물 속에서 플라즈마를 발생시킨 후에 생성된 수산기 $(-\mathrm{OH})$ 는 강 한 산화력을 지닌 방전수를 활용해 과일 세척, 수질 정화, 폐수 처리 등에 살균에 효과적으로 활용되고 있다(Park 등, 2019). 또한, 플라즈마는 활성화, 살균, 촉매의 고유한 특성을 가져 물리적, 화학적 자극으로 씨앗의 발아율이나 새싹 성장률을 향상시킬 수 있다고 보고되고 있다(Yoo, 2015). Ryu 등 (2016)에 따르면 마이크로웨이브 플라즈마 활성수를 처리한 상추와 페튜니아 유묘 처리구가 대조구보다 생육이 더 증가 했다고 보고하였다.

또한, 작물 재배 시 원적외선을 사용하여 작물의 생육을 촉진하는데, Chee(2001)의 연구에 따르면 원적외선은 파장 이 길어 열작용이 큰 전자파로 공진 및 공명 작용이 강해 가 열 매체 없이 직접 작물에 조사로 작물의 모세혈관을 확장 시켜 혈액순환과 세포조직 생성, 생육촉진 및 물질농축에 도 움이 된다고 하였다. 이에 원적외선 처리수에서 성장한 무의 자엽이 1.25 배 높게 성장하였고, 무 크기가 상대적으로 컸다 고 보고되어 있다(Cho, 2009).

따라서 본 연구에서는 담수경 재배환경을 바탕으로 바이 오블록(원적외선)을 활용하고 LED 시간 및 플라즈마 방전수 처리를 달리하여 새싹삼의 생육 변화 및 품질분석을 통해 새 싹삼의 담수경 재배환경 조건을 확립하고자 하였다.

\section{재료 및 방법}

\section{재료}

본 실험에서 사용된 시료는 1년근 종자삼(Panax ginseng
C. A. Meyer)으로 2020년 10-11월 수확해 냉동 저장된 종자 삼(1-year seed ginseng, mother's farm, Jangseong-gun, Jeollanam-do, Korea)을 2021년 2월 22일에 구입하여 상온에 서 해동한 후 test bed에 바로 이식하였다.

\section{생육환경 조건설정}

본 생육실험은 익산시 춘포면에 위치한 더자람 식물원 내 에 스마트팜 베드를 설치하였다. 생육환경에서 생육 test bed 는 $500 \mathrm{~cm} \times 30 \mathrm{~cm} \times 20 \mathrm{~cm}$ 로 제작하고, $50 \mathrm{~cm} \times 30 \mathrm{~cm}$ 스펀지 베드를 test bed 내에 띄워서 담수경 재배하였다. 1 년근 종자 삼을 스펀지 베드에 45개씩 9베드를 test bed에 이식하고 생 육 촉진을 위한 72시간 암막형성 후 7일 간격으로 4주간 생 육을 측정하였다. 새싹삼의 생육처리 조건은 Table 1과 같다.

LED 조건에서 대조구(CGS)는 스탠드 LED(SL-660, LED stand, Samjung inverter Co., Ltd., Hwaseong, Gyeonggi-do, Korea)를 사용하고, $\mathrm{CGS}$ 에 처리한 색온도 $5926\left(\mathrm{CCT}^{\circ} \mathrm{K}\right)$, 광 속(광선속) Luminous flux 475.1( $(\mathrm{lm})$, 광효율 Efficiency 52.26 $\mathrm{lm} / \mathrm{w}$, 연색지수 CRI $84.4 \mathrm{Ra}$, 최대파장 Peak wavelength $446.1 \mathrm{~nm}$, 최종파장 Dominant wavelength $489.4 \mathrm{~nm}$, 조도 Illuminance $3985 \mathrm{Lx}$ 이며, 처리구 TGS에는 식물성장용 LED(Plant Grow Lighting, Custom-made Spectrum, ALLIX Co., Jeonju, Jeollabuk-do, Korea)를 1.5 m LED bar 형식으 로 1줄 처리하였다. 처리구(TGS) $\mathrm{LED}$ 는 색온도 4,390 $\mathrm{CCT}^{\circ} \mathrm{K}$, 광속(광선속) Luminous flux $1,584 \mathrm{~lm}$, 광효율 Efficiency $75.06 \mathrm{~lm} / \mathrm{w}$, 연색지수 CRI $92.1 \mathrm{Ra}$, 최대파장 Peak wavelength $449.4 \mathrm{~nm}$, 최종파장 Dominant wavelength $571.7 \mathrm{~nm}$, 조도Illuminance $2884 \mathrm{Lx}$ 로 설정하였다(Fig. 1). 양액은 수소화 미네랄 양액(HW) $\mathrm{pH} 5.13, \mathrm{EC}(\mathrm{ds} / \mathrm{m})$ 0.31이 며, 조성비(\%)는 K 9.57, $\mathrm{Ca} 8.09, \mathrm{Mg} 14.17, \mathrm{Na} 17.61, \mathrm{Cl}$ 41.15, $\mathrm{NO}_{3}-\mathrm{N}$ 0.61, S 4.82, P 2.24, $\mathrm{Zn} \mathrm{1.31,} \mathrm{Cu} \mathrm{0.05,} \mathrm{Mn}$ 0.95 이고, 발효 양액(NO)은 $\mathrm{pH} 6.53, \mathrm{EC}(\mathrm{ds} / \mathrm{m}) 0.12$ 이며, 조 성비(\%)는 K 12.62, $\mathrm{Ca} 18.08, \mathrm{Mg} 4.30, \mathrm{Na} 9.44, \mathrm{Cl} 46.08$, $\mathrm{NO}_{3}-\mathrm{N}$ 4.04로 구성되어 있다. 설치된 Test bed 안쪽 바닥에 바이오블록(원적외선)을 대조구(CGS)를 제외한 새싹삼 처리 구(TGS)는 2줄로 배열하고, $20 \mathrm{~cm}$ 간격으로 50 개를 배치하 였다. 바이오블록은 현무암 원석을 300-1,000 mesh로 분쇄 후 용해로 $1,500-2,000^{\circ} \mathrm{C}$ 기준으로 용해하여 각 지름 7-8 cm, 두께 2-3 mm, 중량 $40 \mathrm{~g}$ 으로 제조한 것을 사용하였으며, 바 이오블록 방사에너지 $\left(\mathrm{W} / \mathrm{m}^{2} \cdot \mu \mathrm{m}, 37^{\circ} \mathrm{C}\right)$ 는 $3.57 \times 10^{2}$ 이고, 방 사율 $(5-20 \mu \mathrm{m})$ 은 0.926 을 나타냈다. 또한, 대조구(CGS)를 제 외한 모든 처리구(TGS)에 $\mathrm{O}_{2}$ 를 공급하였다. 플라즈마 장치 설계는 총 세 부분으로 나뉘어 전원부, 발진부, 방전부로 센 서 베드에 연결하여 조절하고, $150 \mathrm{~mm} \times 800 \mathrm{~mm}$ 마이크로버 블 제조장치(MVI-408, Wilo Co., Busan, Korea)를 중간부에 
Table 1. Changes in total decay rate and growth of Panax ginseng sprout (PGS) during cultivation

\begin{tabular}{|c|c|c|c|c|c|c|c|}
\hline & & $\begin{array}{c}\text { Total decay rate } \\
(\%)\end{array}$ & $\begin{array}{l}\text { Total length } \\
\text { (cm) }\end{array}$ & $\begin{array}{l}\text { Root } \\
(\mathrm{cm})\end{array}$ & $\begin{array}{l}\text { Stem } \\
(\mathrm{cm})\end{array}$ & $\begin{array}{l}\text { Root thickness } \\
(\mathrm{cm})\end{array}$ & $\begin{array}{c}\text { Number of leaves } \\
\text { (ea) }\end{array}$ \\
\hline Initial & $\mathrm{CON}^{1)}$ & - & - & $10.63 \pm 1.56$ & - & $4.67 \pm 0.69^{b}$ & - \\
\hline \multirow{5}{*}{7 days } & $\mathrm{CGS}^{2)}$ & 5.45 & $16.16 \pm 2.87^{4) b}$ & $11.19 \pm 2.40$ & $4.97 \pm 1.06^{\mathrm{b}}$ & $5.18 \pm 0.64^{b}$ & $7.73 \pm 3.15^{\mathrm{c}}$ \\
\hline & $\mathrm{TGS}^{3)} 1$ & 3.84 & $14.88 \pm 2.89^{c}$ & $11.92 \pm 2.72$ & $2.96 \pm 1.20^{\mathrm{d}}$ & $5.26 \pm 0.54^{\mathrm{ab}}$ & $8.33 \pm 2.45^{\mathrm{bc}}$ \\
\hline & TGS2 & 2.03 & $16.00 \pm 3.08^{\mathrm{ab}}$ & $11.79 \pm 3.08$ & $4.22 \pm 0.74^{\mathrm{c}}$ & $5.41 \pm 0.71^{\mathrm{ab}}$ & $9.80 \pm 3.00^{\mathrm{ab}}$ \\
\hline & TGS3 & 3.64 & $15.55 \pm 2.43^{\mathrm{b}}$ & $11.68 \pm 2.38$ & $3.88 \pm 0.89^{\mathrm{c}}$ & $5.27 \pm 0.76^{\mathrm{ab}}$ & $10.50 \pm 2.85^{\mathrm{a}}$ \\
\hline & TGS4 & 12.73 & $17.19 \pm 2.57^{\mathrm{a}}$ & $11.61 \pm 2.13$ & $5.58 \pm 1.59^{\mathrm{a}}$ & $5.61 \pm 0.85^{\mathrm{a}}$ & $11.07 \pm 2.92^{\mathrm{a}}$ \\
\hline \multicolumn{2}{|c|}{ F-value } & & $3.136^{*}$ & $0.350^{\mathrm{NS}}$ & $23.587^{* * *}$ & $1.719^{\mathrm{NS}}$ & $7.233^{* * *}$ \\
\hline & & $\begin{array}{c}\text { Total decay rate } \\
(\%)\end{array}$ & $\begin{array}{l}\text { Total length } \\
\text { (cm) }\end{array}$ & $\begin{array}{l}\text { Root } \\
(\mathrm{cm})\end{array}$ & $\begin{array}{l}\text { Stem } \\
(\mathrm{cm})\end{array}$ & $\begin{array}{l}\text { Root thickness } \\
(\mathrm{cm})\end{array}$ & $\begin{array}{l}\text { Number of leaves } \\
\text { (ea) }\end{array}$ \\
\hline \multirow{5}{*}{14 days } & CGS & 8.00 & $23.22 \pm 2.14^{\mathrm{b}}$ & $12.14 \pm 1.97^{\mathrm{ab}}$ & $11.08 \pm 1.39^{b}$ & $4.85 \pm 0.66^{\mathrm{c}}$ & $8.77 \pm 2.81^{\mathrm{c}}$ \\
\hline & TGS1 & 4.00 & $23.84 \pm 2.76^{\mathrm{b}}$ & $13.15 \pm 2.74^{\mathrm{a}}$ & $10.67 \pm 1.07^{\mathrm{b}}$ & $5.09 \pm 0.78^{\mathrm{bc}}$ & $10.40 \pm 2.42^{\mathrm{b}}$ \\
\hline & TGS2 & 3.43 & $22.90 \pm 2.65^{\mathrm{b}}$ & $12.20 \pm 2.38^{\mathrm{ab}}$ & $10.70 \pm 1.32^{b}$ & $5.41 \pm 0.68^{b}$ & $11.03 \pm 2.51^{\mathrm{b}}$ \\
\hline & TGS3 & 4.45 & $23.75 \pm 2.74^{\mathrm{b}}$ & $13.43 \pm 2.97^{\mathrm{a}}$ & $10.31 \pm 1.67^{\mathrm{b}}$ & $5.46 \pm 0.62^{b}$ & $11.53 \pm 2.53^{b}$ \\
\hline & TGS4 & 14.18 & $26.30 \pm 3.44^{\mathrm{a}}$ & $11.03 \pm 2.20^{\mathrm{b}}$ & $15.27 \pm 2.11^{\mathrm{a}}$ & $5.92 \pm 0.79^{\mathrm{a}}$ & $12.87 \pm 2.53^{\mathrm{a}}$ \\
\hline \multicolumn{2}{|c|}{ F-value } & & $6.990^{* * *}$ & $4.407^{* *}$ & $52.965^{* * *}$ & $9.863^{* * *}$ & $10.688^{* * *}$ \\
\hline & & $\begin{array}{c}\text { Total decay rate } \\
(\%)\end{array}$ & $\begin{array}{l}\text { Total length } \\
\text { (cm) }\end{array}$ & $\begin{array}{l}\text { Root } \\
(\mathrm{cm})\end{array}$ & $\begin{array}{l}\text { Stem } \\
(\mathrm{cm})\end{array}$ & $\begin{array}{l}\text { Root thickness } \\
(\mathrm{cm})\end{array}$ & $\begin{array}{l}\text { Number of leaves } \\
\text { (ea) }\end{array}$ \\
\hline \multirow{5}{*}{21 days } & CGS & 8.36 & $22.80 \pm 2.67^{\mathrm{c}}$ & $11.60 \pm 2.10^{\mathrm{c}}$ & $11.20 \pm 1.80^{\mathrm{c}}$ & $4.47 \pm 0.82^{\mathrm{c}}$ & $8.47 \pm 2.96^{\mathrm{b}}$ \\
\hline & TGS1 & 4.65 & $30.45 \pm 3.14^{\mathrm{a}}$ & $12.59 \pm 2.78^{\mathrm{ab}}$ & $17.86 \pm 2.03^{\mathrm{a}}$ & $4.57 \pm 0.55^{\mathrm{ab}}$ & $11.17 \pm 2.64^{\mathrm{a}}$ \\
\hline & TGS2 & 4.24 & $29.12 \pm 3.92^{b}$ & $13.15 \pm 2.61^{\mathrm{a}}$ & $15.98 \pm 2.44^{b}$ & $4.92 \pm 0.72^{\mathrm{b}}$ & $11.23 \pm 2.56^{\mathrm{a}}$ \\
\hline & TGS3 & 4.65 & $30.82 \pm 3.89^{\mathrm{a}}$ & $13.89 \pm 3.54^{\mathrm{a}}$ & $16.93 \pm 2.47^{\mathrm{ab}}$ & $4.90 \pm 0.57^{\mathrm{b}}$ & $12.00 \pm 2.94^{\mathrm{a}}$ \\
\hline & TGS4 & 15.09 & $28.26 \pm 3.85^{\mathrm{b}}$ & $11.34 \pm 3.04^{\mathrm{c}}$ & $16.91 \pm 3.26^{\mathrm{ab}}$ & $5.54 \pm 0.58^{\mathrm{a}}$ & $12.67 \pm 3.10^{\mathrm{a}}$ \\
\hline \multicolumn{2}{|c|}{ F-value } & & $25.223^{* * *}$ & $4.154^{* *}$ & $34.861^{* * *}$ & $12.134^{* * *}$ & $9.471^{* *}$ \\
\hline
\end{tabular}

${ }^{1)} \mathrm{CON}$, initial ginseng seed.

${ }^{2)}$ CGS, control ginseng sprout.

${ }^{3)}$ TGS, treated ginseng sprout.

${ }_{*}^{4}$ Values $\underset{* *}{\operatorname{are}}$ mean \pm SD. Different letters within a column are significantly different $(\mathrm{p}<0.05)$.

${ }^{*} \mathrm{p}<0.05,{ }^{* *} \mathrm{p}<0.01,{ }^{* * *} \mathrm{p}<0.000$. NS, not significantly.

연결하여 처리구 TGS2, TGS3, TGS4에만 플라즈마 방전수 를 공급하였다. 수경 재배 시스템의 양액 순환 과정은 1 일 1 회 회수되도록 설정하고, 재활용 순환수 조건을 EC 0.5 이하, $\mathrm{pH}$ 6.5-7.0, DO 6-10 ppm으로 설정하였다. 스마트팜 내 온 도 $21.0 \pm 3.0^{\circ} \mathrm{C}$, 생육베드 내 온도 $20.0 \pm 2.0^{\circ} \mathrm{C}$, 습도 $55 \pm 5 \%$ $\mathrm{RH}$ 를 유지하였다.

생육 기간은 총 21일간으로 종자삼을 2021년 2월 22일에 이식하고, 3월 2일까지 7일간 발아 관찰 후, 7 일 간격으로 분 석하여 21일차인 2021년 3월 15 일에 재배를 종료하였다. 재 배하는 동안 생육 변화를 측정하였다.

\section{생육변화 측정}

종자삼은 스펀지 베드에 이식 후 암실환경을 72시간 조성 후 7일 간격으로 21 일차까지 발아율, 뿌리 부패율 그리고 생 육 변화를 측정하였다. 생육 변화 측정방법은 Seong 등(2019) 의 방법을 참고하여 측정하였다. 재배일수별 새싹삼의 지상 부인 잎 개수와 줄기 길이와 지하부인 뿌리 두께와 길이를 각각 측정하였다. 줄기 부분은 뇌두 시작부터 잎자루 시작 부 위까지를 측정하고, 새싹삼 두께(근경)는 뇌두 부분에서 $1 \mathrm{~cm}$ 떨어진 부위에 버니어캘리퍼스(Metric 500-704-20 waterproof IP67 digital vernier caliper, Mitutoyo Co., Kawasaki, Japan) 
(A)

\begin{tabular}{|c|c|c|c|c|c|c|}
\hline Samples & $\begin{array}{l}\text { LED time } \\
\text { (h) }\end{array}$ & $\begin{array}{l}\text { LED illuminance } \\
\text { (Lx) }\end{array}$ & $\begin{array}{c}\text { Nutrient } \\
\text { solution } \\
\text { (ratio } 1: 1000 \text { ) }\end{array}$ & Bioblock & $\begin{array}{c}\text { Plasma } \\
\text { discharge water }\end{array}$ & $\begin{array}{c}\mathrm{O}_{2} \\
\text { supply }\end{array}$ \\
\hline $\mathrm{CGS}^{1)}$ & $9-18(9 \mathrm{~h})$ & 3,985 & $\times$ & $x$ & $\times$ & $x$ \\
\hline $\mathrm{TGS}^{2)} 1$ & $9-18(9 \mathrm{~h})$ & 2,884 & $\mathrm{NO}^{3)}$ & 0 & $x$ & 0 \\
\hline TGS2 & $9-18(9 \mathrm{~h})$ & 2,884 & $\mathrm{HW}^{4)}$ & 0 & 0 & 0 \\
\hline TGS3 & $9-18(9 \mathrm{~h})$ & 2,884 & NO & 0 & 0 & 0 \\
\hline TGS4 & $24 \mathrm{~h}$ & 2,884 & $\mathrm{NO}$ & 0 & 0 & 0 \\
\hline
\end{tabular}

(B)

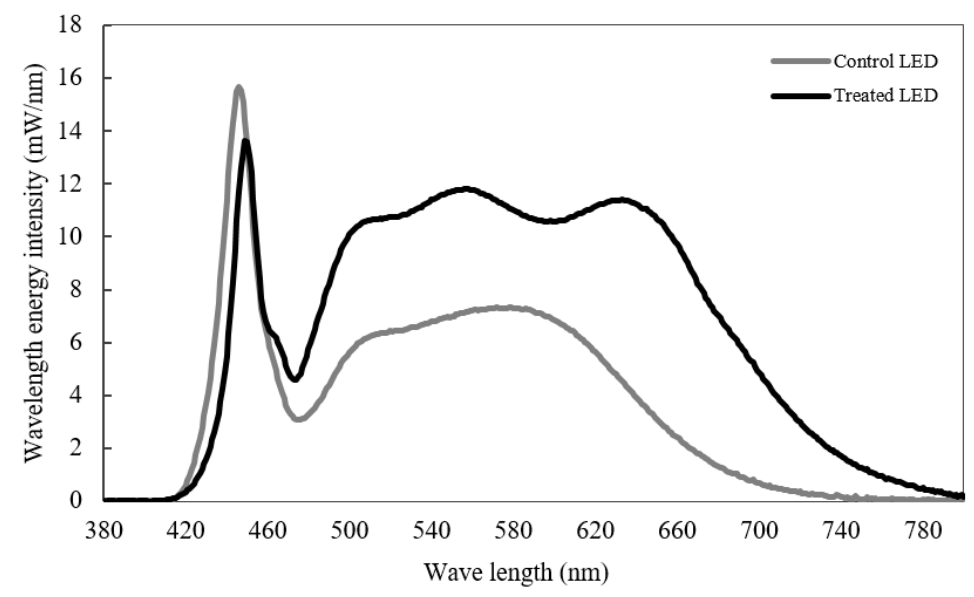

(C)

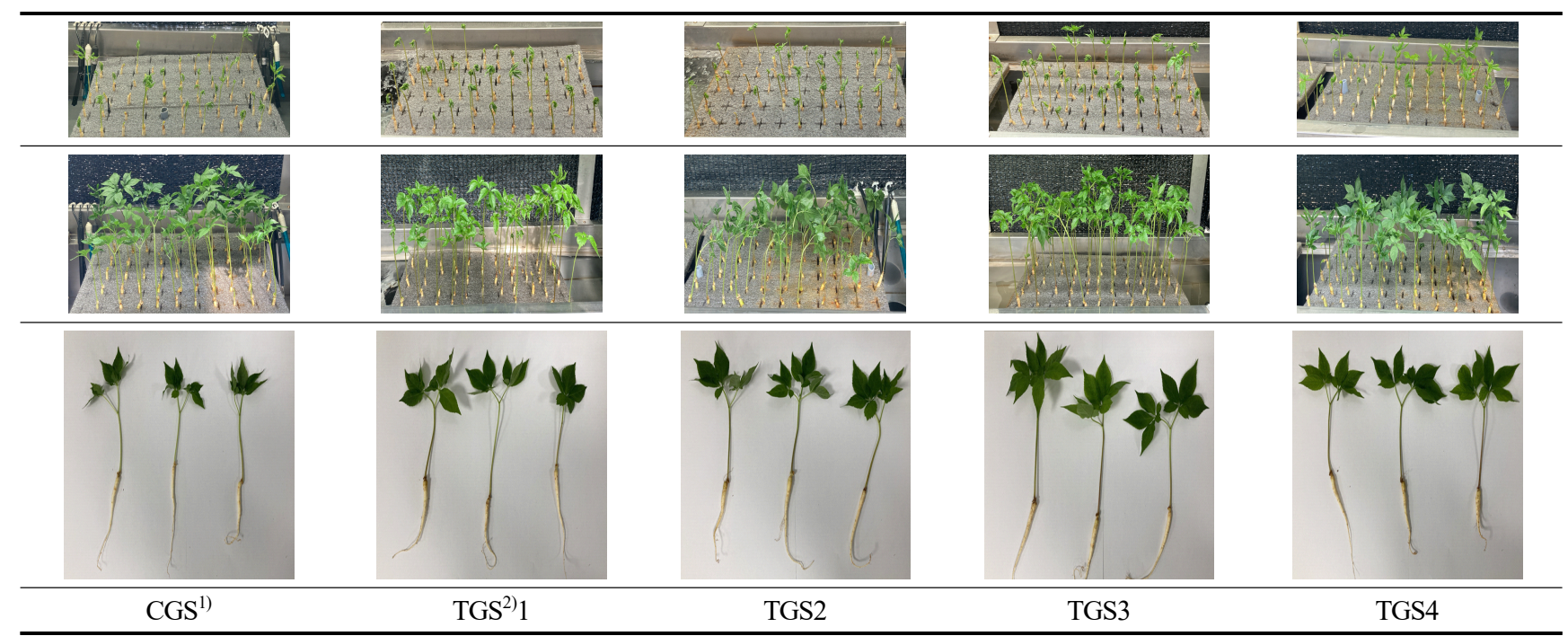

Fig. 1. Panax ginseng sprout (PGS) treatment and growth conditions.

(A) This table shows the conditions for growth environment treatment. ${ }^{1)} \mathrm{CGS}$, control ginseng sprout. ${ }^{2)} \mathrm{TGS}$, treated ginseng sprout. ${ }^{3)} \mathrm{NO}$, minerals nutrient solution. ${ }^{4} \mathrm{HW}$, hydrogenation nutrient solution. (B) The control LED was treated on the CGS (control ginseng sprout) and the treated LED was treated on the TGS (treated ginseng sprout). Control LED main wave length is $450 \mathrm{~nm}$, Treated LED main wave length is $455 \mathrm{~nm}$, $645 \mathrm{~nm}$. (C) It is a picture to sprout of ginseng on the 7 days from the top left and a picture of ginseng sprout on the 21 days from the middle and last left. ${ }^{1)} \mathrm{CGS}$, control ginseng sprout. ${ }^{2}$ TGS, treated ginseng sprout. 
를 이용하여 측정하였다. 지하부 뿌리(근장)는 뇌두 부분부터 뿌리 가장 끝부분까지 $30 \mathrm{~cm}$ 자를 이용하여 측정하였다. 모 든 시료는 스마트팜 내에 식재된 새싹삼을 측정하였고 Test bed 당 45개씩 식재된 스펀지 베드 9개 중 3 개를 무작위로 뽑아 한 시료 당 30 개씩 측정하여 평균값을 나타냈다.

\section{잎 색도변화 측정}

새싹삼 잎의 색도는 7 일에서 21 일 차까지 7 일 간격으로 측 정하였다. 7 일차 새싹삼 잎은 작아 새싹삼을 3 개씩 모아서 잎 의 중간 부분을 측정하고 14 일차와 21 일차는 잎 하나의 중간 부분을 측정하였다. 색차계(CM-700d, Minolta Inc., Tokyo, Japan)를 사용하여 Hunter $\mathrm{L}, \mathrm{a}, \mathrm{b}$ 값을 측정한 뒤 평균값으 로 나타내었다. L value는 0 (black), +100 (white), a value는 60(redness), -60(greenness), b value는 +60(yellowness), -60 (blueness)으로 수치화하였다. 시료는 각 5 회 반복하여 측정 하였다. 백색판 값은 L: $99.30, a:-0.09, b:-0.12$ 로 맞추어 실험하였다.

\section{조사포닌 분석}

조사포닌 함량은 건강기능식품공전(2004)에 나와 있는 ‘인삼/홍삼성분함유 제품' 실험 방법으로 수정하여 분석하였 다. 인삼 생 시료를 분쇄한 후에 시료 약 $5 \mathrm{~g}$ 을 정밀히 달아 서 $250 \mathrm{~mL}$ 환류 플라스크에 넣고 부탄올 $50 \mathrm{~mL}$ 를 가하여 $70-80^{\circ} \mathrm{C}$ 의 항온수조(BS-21 Shaking Water Bath, Jeiotech Co., LTD., Daejeon, Korea)에서 1시간 환류 추출한 후 여과 하였다. 잔류물에는 부탄올 용액 $50 \mathrm{~mL}$ 가하여 한번 더 환류 추출하여 이 작업을 1 회 반복하여 추출하였다. 추출한 후 $250 \mathrm{~mL}$ 분액 깔대기에 옮기고 증류수 $50 \mathrm{~mL}$ 를 가한 후 격 렬히 흔들어서 물과 부탄올 층이 완전히 분리될 때까지 정치 하였다. 그 후 물 층을 제거하고 부탄올 층(상층)을 미리 항량 한 농축 플라스크에 넣고 감압농축하였다. 농축물에는 에테 르 $50 \mathrm{~mL}$ 를 가하여 약 $36^{\circ} \mathrm{C}$ water bath에서 30 분간 환류 냉 각하며 추출하고, 탈지한 뒤 에테르층을 분액하여 제거하였 다. 잔류물을 항량이 될 때까지 $105^{\circ} \mathrm{C}$ 에서 건조하고 데시케 이터에서 30 분간 방랭한 후 무게를 측정하였다. 조사포닌 함 량 계산식은 아래와 같다.

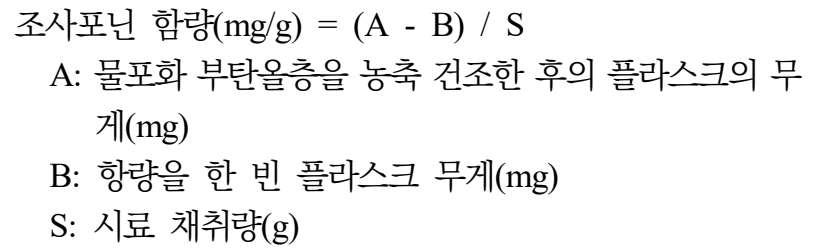

\section{추출물 제조}

초기 종자삼 및 21일간 재배한 새싹삼(TGS)을 각 베드에
서 무작위로 채취하였다. 잎과 뿌리 모두 한꺼번에 동결건조 한 후 분쇄하여 사용하였다. 추출방법은 Lee 등(2020)의 방 법을 참고하여 추출하였다. 동결건조 새싹삼 분말 $1 \mathrm{~g}$ 에 $80 \%$ Ethanol $20 \mathrm{~mL}$ 를 넣고 $80^{\circ} \mathrm{C}$ 항온수조(BS-21 Shaking water bath)에서 $100 \mathrm{rpm}, 3$ 시간 진탕 추출하고, $4^{\circ} \mathrm{C}, 10,000 \mathrm{rpm}$ (Centrifuge 5804R, Eppendorf AG, Hamburg, Germany)에 서 15 분간 원심분리 후 $0.45 \mu \mathrm{m}$ Syringe filter(RC25 syringe filter 17765, Sartorius AG, Göttingen, Germany)로 여과하였 다. 추출시료는 $0-4^{\circ} \mathrm{C}$ 에 보관한 후 희석하여 각 실험에 사용 하였다.

\section{총폴리페놀 함량분석}

총폴리페놀 함량은 Singleton과 Rossi(1965)의 FolinDenis 방법을 수정하여 분석하였다. 일정 농도로 희석한 시 료 $100 \mu \mathrm{L}$ 에 $2 \%$ 의 $\mathrm{Na}_{2} \mathrm{CO}_{3} 2 \mathrm{~mL}$ 를 첨가하여 3 분 동안 상온 에서 방치시킨 다음 $1 \mathrm{~N}$ Folin-Ciocalteu 시약(Sigma-Aldrich Co., St. Louis, MO, USA) $100 \mu \mathrm{L}$ 를 넣은 후 $35^{\circ} \mathrm{C}$ 에서 11 분 반응시켰다. 이후 흡광기기(Jasco V-730 Spectrophotometer, Jasco Corp., Tokyo, Japan)를 사용하여 $750 \mathrm{~nm}$ 에서 흡광도 를 측정하였다. 총폴리페놀 함량은 gallic acid(SigmaAldrich Co.)를 표준물질로 하여 산출하였고, 동결건조 새싹 삼 $100 \mathrm{~g}$ 당 $\mathrm{mg}$ gallic acid equivalent(GAE, dry basis)로 함 량을 나타냈다.

\section{총플라보노이드 함량분석}

총플라보노이드 함량은 Moreno 등(2000)의 방법을 수정 하여 분석하였다. 시료 $100 \mu \mathrm{L}$ 에 증류수 $1 \mathrm{~mL}$ 와 $5 \% \mathrm{NaNO}_{2}$ 용액 $75 \mu \mathrm{L}$ 를 넣은 후 상온에서 5 분간 반응시켰다. 이후 $10 \% \mathrm{AlCl}_{3} \cdot 6 \mathrm{H}_{2} \mathrm{O}$ 용액 $150 \mu \mathrm{L}$ 를 첨가하고 6 분 동안 상온 에서 방치시킨 후, $1 \mathrm{M} \mathrm{NaOH}$ 용액 $500 \mu \mathrm{L}$ 를 첨가하여 11분 동안 발색시키고, $510 \mathrm{~nm}$ 에서 흡광도를 측정하였다. 총플라 보노이드 함량은 (+)-catechin hydrate(Sigma-Aldrich Co.) 표 준곡선을 이용하여 산출하였고, 동결건조 새싹삼 $100 \mathrm{~g}$ 당 $\mathrm{mg}(+)$-catechin hydrate equivalent(CHE, dry basis)로 함량 을 나타냈다.

\section{엽록소 및 총카로티노이드 함량측정}

엽록소 및 총카로티노이드 함량은 Lichtenthaler 등(1987) 의 방법을 수정하여 측정하였다. 동결건조 시료 $0.1 \mathrm{~g}$ 에 $80 \%$ Acetone을 첨가한 $10 \mathrm{~mL}$ 를 48 시간 $0-4^{\circ} \mathrm{C}$ 에서 냉암소 보관 하여 색소를 추출하였다. 추출시료는 흡광기기(Jasco V-730 Spectrophotometer)를 사용하여 $663,645,470 \mathrm{~nm}$ 에서 측정 하고 아래의 식을 이용하여 계산하였다.

Chlorophyll a $(\mathrm{mg} / \mathrm{g} \mathrm{FW})=12.7 \times \mathrm{A}_{663}-2.69 \times \mathrm{A}_{645}$ 
Chlorophyll $\mathrm{b}=22.9 \times \mathrm{A}_{645}-4.68 \times \mathrm{A}_{663}$

Total chlorophyll $(\mathrm{a}+\mathrm{b})=20.29 \times \mathrm{A}_{645}+8.02 \times \mathrm{A}_{663}$

Total carotenoid $=\left(1,000 \times \mathrm{A}_{470}-1.82 \times\right.$ chl. a -85.02 $\times$ chl. b) / 198

\section{ABTS 라디칼 소거능 분석}

ABTS(2,2-azino-bis-(3-ethylbenzothiazoline-6-sulfonic acid) 라디칼 소거능은 $\operatorname{Re}$ 등(1999)의 방법을 수정하여 분석 하였다. $7 \mathrm{mM} \mathrm{ABTS}$ 용액과 $2.45 \mathrm{mM}$ potassium persulfate 를 1:1로 혼합한 후 암소에서 약 24시간 반응시켰다. 이후 실 험 직전에 ABTS 용액을 $735 \mathrm{~nm}$ 에서 흡광도가 $1.4 \pm 0.01$ 이 되도록 phosphate buffer saline(pH 7.4)으로 희석하여 사용하 였다. 희석된 $\mathrm{ABTS}$ 용액 $1 \mathrm{~mL}$ 를 일정농도로 희석한 시료 $50 \mu \mathrm{L}$ 에 첨가하여 암소에서 30 분간 실온 반응시켰다. 이후 흡광기기(Jasco V-730 Spectrophotometer)를 사용하여 735 $\mathrm{nm}$ 에서 흡광도를 측정하였다. 측정흡광도는 L-ascorbic acid (Sigma-Aldrich Co.)를 이용하여 만든 표준곡선을 이용하여 $\mathrm{ABTS}$ 라디칼 소거능 결과값을 백분율(\%)로 나타냈다.

\section{통계분석}

실험결과는 SPSS프로그램(21.00, IBM Corp., SPSS Inc, Chicago, IL, USA)을 이용하여 분산분석(ANOVA)법을 실시 하였고, 3회 반복 실험하고 실험군 간의 유의성은 Duncan's multiple range test로 $\mathrm{p}<0.05$ 수준에서 유의적 차이를 검증하 였다.

\section{결과 및 고찰}

\section{발아율 및 부패율}

새싹삼의 발아율 및 생육 일수에 따른 뿌리 부패율(Table $1)$ 은 다음과 같다. 새싹삼 7 일차 대조구 $(\mathrm{CGS})$ 는 $95.68 \%$ 의 발아율을 보였으며, 처리구(TGS) 발아율은 각각 TGS1은 $99.60 \%, \mathrm{TGS} 299.40 \%, \mathrm{TGS} 399.80 \%$ 그리고 TGS4는 $99.82 \%$ 로 대조구보다 높은 발아율(\%)을 보였다. 이는 양액 을 처리하지 않은 CGS에서 미발아 종자삼이 많이 분석되었 다. 반면에 대부분 발아한 TGS는 양액뿐 아니라, 초기 생육 에 영향을 주는 바이오블록(원적외선)의 영향으로 판단되는 데, Park 등(2016)의 연구에 따르면 화산력 바이오블록을 처 리한 페레니얼 레이그라스의 발아 1 주 때 다른 처리구에 비 해 발아율이 $80-85 \%$ 증가되었다고 보고된 바와 비슷한 경향 으로 보여진다.

대조구 CGS 7일차 부패율은 $5.45 \%$ 를 처리구는 각각 TGS1 은 3.84\%, TGS2 2.03\%, TGS3 3.64\% 그리고 TGS4는 $12.73 \%$ 로 다른 처리구보다 높은 부패율(\%)을 보였다. 재배 일수가
증가할수록, $\mathrm{CGS}$ 는 총 부패율이 $8.36 \%$ 로 높은 반면에 처리 구 TGS1, TGS2 및 TGS3는 4.24-4.65\%로 낮은 부패율(\%) 을 나타냈다. 이는 Ryu 등(2004)의 연구에서 플라즈마 방전 수 처리했을 때 대장균 $4 \log$ 이상의 살균능을 보였고, 5일간 밀폐용기에 처리하였을 때도 $4 \log$ 이상의 살균 지속력을 보 였다고 보고하였다. 따라서 플라즈마 방전수에 잔존된 라디 컬의 영향으로 재배수 오염 저감 및 미생물 살균에 영향을 줬을 것으로 판단된다. 그러나 처리구 TGS4는 $15.09 \%$ 로 유 의적으로 $(\mathrm{p}<0.05)$ 높은 부패율을 보였는데, 이는 다른 처리 구에 비해 조사시간이 긴 TGS4는 재배수 온도가 높아져 세 균증식에 영향을 준 것으로 판단된다.

\section{생육 변화}

새싹삼 재배 기간 중 생육 변화 측정 결과는 Table 1과 같 다. 7일차에서는 뿌리길이를 제외하고 대조구(CGS)보다 처 리구(TGS)에서 높은 경향으로 나타났다. TGS4가 7일차와 14 일차에서 다른 처리구에 비해 유의적으로 $(\mathrm{p}<0.05)$ 높게 나 타났는데, 이는 Park 등(2012)의 연구에서 광조사를 24시간 으로 처리한 상추에서 높이, 줄기 및 엽면적 등 가장 높은 값 을 보였으며, 식물에서 초장은 온도와 관계없이 광원의 주기 가 길어짐에 따라 증가한다는 보고와 일치하였다(Erwin 등, 1991). 그러나 21일차에는 전체길이 증가율이 다른 처리구에 비해 낮은데, 이는 광의 강도 및 조사시간이 식물의 생육에 영향을 주는데 연속적인 광조사로 인해 식물에 스트레스로 작용한 것으로 판단된다(Park 등, 2012). 21일차 또한 CGS보 다 처리구 $\mathrm{TGS}$ 에서 생육 증가율이 높게 나타났는데, 이는 Lee 등(2016)의 연구에서 단색파장을 혼합한 LED에서 재배 했을 때 생장과 바이오매스가 증가한다고 보고하였고, 그 중 잎의 광합성 관련 기관의 발달과 전분 축적에 효과적인 적색 파장이 식물 생장에 관여한다는 결과로 처리구의 새쌈삼 생 육에 영향을 받았을 것으로 판단된다(Saebo 등, 1995). 그에 비해 CGS에는 청색광의 비율이 높은데, $\mathrm{Kim}$ 등(2017)의 연 구에서 청색광의 비율이 $80 \%$ 이상 $\mathrm{LED}$ 를 처리했을 때, 상 추의 잎장 및 생체중이 감소한다는 결과를 미루어 보아 CGS $\mathrm{LED}$ 의 대부분을 차지하는 청색광으로 인해 생육에 영향을 줬을 것으로 판단된다.

전체 길이에서 $\mathrm{TGS}$ 가 $\mathrm{CGS}$ 에 비해 유의적으로 $(\mathrm{p}<0.05)$ 높 게 나타났다. 그 중 수소화 미네랄 양액 $(\mathrm{HW})$ 을 처리한 처리 구보다 발효 양액 $(\mathrm{NO})$ 을 처리한 처리구에서 더 높은 값을 나 타냈다. 이는 $\mathrm{Yi}$ 등(2013)의 연구에서 $\mathrm{NO}_{3}{ }^{-}$를 $100 \%$ 처리한 고추의 생장에서 생육이 우수하다고 하였으며, $\mathrm{NO}_{3}{ }^{-}$가 많을 수록 생식생장에 유리하게 작용한다고 보고하였다. 본 연구 에서 $\mathrm{NO}_{3}-\mathrm{N}$ 의 비율이 높은 $\mathrm{NO}$ 양액 처리구 결과와 비슷한 경향을 나타냈다. 초장 길이 및 엽수에서 Shin 등(2013)의 연 
구에 따르면 $\mathrm{NO}_{3}-\mathrm{N}$ 의 비율을 높게 한 상추에서 작물 생장이 우수하였으며, 초장 길이 및 엽수 또한 다른 처리구보다 많다 는 결과를 보고하여, $\mathrm{NO}$ 양액을 처리한 처리구에서 생장이 우수한 것으로 보이고, 양액 종류 및 양액 조성으로 인해 처리 구 간 생장 반응에서 차이를 나타냈다.

\section{잎 색도 변화}

새싹삼의 생육기간 동안 잎 색도변화 측정 결과는 Table 2 와 같다. Hunter L값이 밝기를 나타내는데 값이 $(+)$ 가 될수 록 명도가 높아지고 (-)가 될수록 명도가 낮아지는데, 7일차에 는 대조구(CGS)가 50.10으로 나타나고 처리구(TGS)는 30.7333.59로 CGS보다 명도가 낮게 나타났다. 또한, 21일차에 L 값 $\mathrm{CGS}$ 는 38.52로 나타나고 $\mathrm{TGS}$ 는 28.26-33.89로 나타나, 대조구 잎이 더 밝은 것으로 측정되었다. Hunter a값은 (+)값 이 될수록 적색 정도를 나타내고, (-)값일수록 녹색 정도를 나 타낸다. 7 일차보다 21 일차에 녹색정도가 모든 시료에서 높게 측정되었다. 21일차에 CGS가 -12.47로 TGS보다 녹색정도가 강하게 나타났다. Hunter b값은 (+)값이 될수록 황색 정도를 나타내고, (-)값일수록 청색 정도를 나타낸다. 7일차에는 CGS 가 24.32 로 유의적으로 $(\mathrm{p}<0.05)$ 높게 측정된 반면, $\mathrm{TGS4} 4$ 는 11.78 로 낮게 측정되었다. 21 일차에는 TGS가 모든 비슷한 경향을 보이고, CGS가 14.48 로 다른 처리구에 비해 황색정도 가 강하게 나타났다.

\section{엽록소 및 총카로티노이드 함량}

새싹삼의 엽록소 및 총카로티노이드 함량은 Table 3 과 같
다. 진한 녹색을 나타내는 엽록소 a 함량에서 대조구(CGS)가 유의적으로( $\mathrm{p}<0.05)$ 높게 나타났는데, 이는 $\mathrm{CGS}$ 에 청색광 비 율이 높은 LED 처리로 인해 새싹삼 엽록소 합성에 영향을 준 것으로 판단된다. 색광은 엽록소 함량 및 주로 잎의 기능 발달 에 작용하는데, Son 등(2012)의 연구에 따르면 청색 LED 처 리구에서 엽록소 함량이 생육 기간 중 점차 증가하고 또한 생 육을 촉진시켜 청색광이 광합성에 밀접한 관계가 있음을 보고 하였으며, Yang 등(1997)에서도 인삼 모상근의 클로로필 생 성은 청색 파장에서 높았다고 하였다. 또한, 처리구 TGS4가 엽록소 $\mathrm{a}$ 뿐 아니라, 녹황색을 나타내는 엽록소 $\mathrm{b}$ 와 총엽록소 함량에서 유의적으로 $(\mathrm{p}<0.05)$ 높게 나타났다. 이는 다른 시료 에 비해 광 조사시간이 길어 광합성에 영향을 준 것으로 판단 되는데, Park 등(2012)에 따르면 광의 세기뿐 아니라, 노출 시 간도 식물의 광합성에 영향을 준다고 보고하였으며 적색광은 잎의 광합성 관련 기관의 발달과 전분 축적에 효과적이라는 보고된 바로 처리구(TGS)의 LED에 포함된 적색광 및 조사시 간으로 엽록소 축적에 영향을 준 것으로 판단된다(Lee 등, 2016). 이로써 엽록소의 함량은 광의 노출시간 및 LED의 적 색광 $(\mathrm{R})$ : 청색광 $(\mathrm{B})$ 의 비율에 영향이 있다고 보여진다.

총카로티노이드 함량은 9-18 h 처리한 TGS 간 비슷한 함 량을 보였으나, $24 \mathrm{~h}$ 처리한 TGS4의 총카로티노이드 함량은 유의적으로 $(\mathrm{p}<0.05)$ 급격히 감소하는 결과를 보였다. Yang 등(1997)의 연구에서 광량이 높은 인삼 모상근 처리구에서 카로티노이드가 급격히 감소하는 양상 나타냈다고 보고하였 는데, 위의 결과와 일치하는 양상을 나타냈다. 이에 새싹삼 재배 시 새싹삼 잎의 엽록소 및 총카로티노이드 생성에 적절

Table 2. Hunter color value of Panax ginseng sprout (PGS) leaves during cultivation

\begin{tabular}{|c|c|c|c|c|c|c|c|c|c|}
\hline \multirow[b]{2}{*}{ Days } & \multicolumn{3}{|c|}{$\mathrm{L}$} & \multicolumn{3}{|c|}{$\mathrm{a}$} & \multicolumn{3}{|c|}{$\mathrm{b}$} \\
\hline & 7 & 14 & 21 & 7 & 14 & 21 & 7 & 14 & 21 \\
\hline CGS $^{1)}$ & $\begin{array}{c}50.10 \\
\pm 2.50^{3) \mathrm{a}}\end{array}$ & $\begin{array}{l}37.13 \\
\pm 7.22^{\mathrm{a}}\end{array}$ & $\begin{array}{l}38.52 \\
\pm 5.23^{\mathrm{a}}\end{array}$ & $\begin{array}{l}-13.15 \\
\pm 0.87^{b}\end{array}$ & $\begin{array}{l}-12.84 \\
\pm 0.70^{\mathrm{b}}\end{array}$ & $\begin{array}{l}-12.47 \\
\pm 1.77^{\mathrm{b}}\end{array}$ & $\begin{array}{l}24.32 \\
\pm 1.28^{\mathrm{a}}\end{array}$ & $\begin{array}{l}18.70 \\
\pm 1.54^{\mathrm{a}}\end{array}$ & $\begin{array}{l}14.48 \\
\pm 2.30^{\mathrm{a}}\end{array}$ \\
\hline $\mathrm{TGS}^{2)} 1$ & $\begin{array}{r}31.40 \\
\pm 5.64^{\mathrm{b}}\end{array}$ & $\begin{array}{c}31.88 \\
\pm 2.22^{\mathrm{b}}\end{array}$ & $\begin{array}{r}33.89 \\
\pm 1.90^{\mathrm{b}}\end{array}$ & $\begin{array}{l}-7.69 \\
\pm 2.91^{\mathrm{a}}\end{array}$ & $\begin{array}{l}-10.15 \\
\pm 0.68^{\mathrm{a}}\end{array}$ & $\begin{array}{l}-11.21 \\
\pm 1.49^{\mathrm{ab}}\end{array}$ & $\begin{array}{c}12.75 \\
\pm 4.84^{\mathrm{bc}}\end{array}$ & $\begin{array}{c}12.47 \\
\pm 1.00^{\mathrm{b}}\end{array}$ & $\begin{array}{c}11.63 \\
\pm 2.01^{\mathrm{b}}\end{array}$ \\
\hline TGS2 & $\begin{array}{l}33.55 \\
\pm 2.86^{\mathrm{b}}\end{array}$ & $\begin{array}{c}33.24 \\
\pm 1.45^{\mathrm{ab}}\end{array}$ & $\begin{array}{c}31.55 \\
\pm 1.08^{\mathrm{bc}}\end{array}$ & $\begin{array}{l}-8.31 \\
\pm 1.72^{\mathrm{a}}\end{array}$ & $\begin{array}{l}-10.42 \\
\pm 0.90^{\mathrm{a}}\end{array}$ & $\begin{array}{l}-10.33 \\
\pm 0.54^{\mathrm{a}}\end{array}$ & $\begin{array}{c}15.95 \\
\pm 1.19^{\mathrm{b}}\end{array}$ & $\begin{array}{c}13.48 \\
\pm 1.69^{\mathrm{b}}\end{array}$ & $\begin{array}{c}10.86 \\
\pm 1.19^{\mathrm{b}}\end{array}$ \\
\hline TGS3 & $\begin{array}{r}33.59 \\
\pm 3.47^{b}\end{array}$ & $\begin{array}{c}33.17 \\
\pm 2.22^{\mathrm{ab}}\end{array}$ & $\begin{array}{c}32.05 \\
\pm 0.10^{\mathrm{b}}\end{array}$ & $\begin{array}{c}-9.28 \\
\pm 1.70^{\mathrm{a}}\end{array}$ & $\begin{array}{l}-9.80 \\
\pm 1.12^{\mathrm{a}}\end{array}$ & $\begin{array}{l}-10.41 \\
\pm 1.77^{\mathrm{a}}\end{array}$ & $\begin{array}{c}14.93 \\
\pm 2.32^{\mathrm{bc}}\end{array}$ & $\begin{array}{c}12.54 \\
\pm 1.62^{\mathrm{b}}\end{array}$ & $\begin{array}{c}10.46 \\
\pm 0.85^{\mathrm{b}}\end{array}$ \\
\hline TGS4 & $\begin{array}{l}30.73 \\
\pm 2.17^{\mathrm{b}}\end{array}$ & $\begin{array}{c}30.53 \\
\pm 0.74^{\mathrm{b}}\end{array}$ & $\begin{array}{l}28.26 \\
\pm 1.09^{c}\end{array}$ & $\begin{array}{l}-9.36 \\
\pm 1.06^{\mathrm{a}}\end{array}$ & $\begin{array}{l}-10.79 \\
\pm 0.45^{\mathrm{a}}\end{array}$ & $\begin{array}{l}-10.16 \\
\pm 0.28^{\mathrm{a}}\end{array}$ & $\begin{array}{l}11.78 \\
\pm 1.80^{\mathrm{c}}\end{array}$ & $\begin{array}{c}12.22 \\
\pm 0.52^{\mathrm{b}}\end{array}$ & $\begin{array}{c}11.63 \\
\pm 0.53^{\mathrm{b}}\end{array}$ \\
\hline F-value & $25.697^{* * *}$ & $2.351^{\mathrm{NS}}$ & $10.608^{* * *}$ & $6.994^{* *}$ & $11.138^{* * *}$ & $3.745^{*}$ & $17.526^{* * *}$ & $20.559^{* * *}$ & $5.278^{* * *}$ \\
\hline
\end{tabular}

${ }^{1)}$ CGS, control ginseng sprout.

${ }^{2)}$ TGS, treated ginseng sprout.

${ }^{3)}$ Values are mean $\pm S D$. Different letters within a column are significantly different $(\mathrm{p}<0.05)$.

${ }^{*} \mathrm{p}<0.05,{ }^{* *} \mathrm{p}<0.01,{ }^{* * *} \mathrm{p}<0.000$. NS, not significantly. 
Table 3. The contents of antioxidant and functional components of Panax ginseng sprout (PGS)

\begin{tabular}{|c|c|c|c|c|c|c|c|c|}
\hline \multirow[t]{2}{*}{ Samples } & $\begin{array}{c}\text { Chlorophyll } \\
\text { a }\end{array}$ & $\begin{array}{c}\text { Chlorophyll } \\
\text { b }\end{array}$ & $\begin{array}{c}\text { Total } \\
\text { chlorophyll } \\
(\mathrm{a}+\mathrm{b})\end{array}$ & $\begin{array}{c}\text { Total } \\
\text { carotenoid }\end{array}$ & \multirow[t]{2}{*}{$\begin{array}{l}\text { Total saponin } \\
(\mathrm{mg} / \mathrm{g})\end{array}$} & \multirow{2}{*}{$\begin{array}{l}\text { Total polyphenol } \\
\left(\mathrm{mg} \mathrm{GAE}^{4)}\right) \\
/ 100 \mathrm{~g} \mathrm{sample)}\end{array}$} & \multirow{2}{*}{ 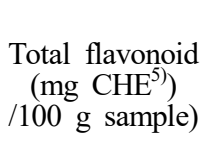 } & \multirow{2}{*}{$\begin{array}{l}\text { ABTS free radical } \\
\text { scavenging activity } \\
(5,000 \mu \mathrm{g} / \mathrm{mL})(\%)\end{array}$} \\
\hline & \multicolumn{4}{|c|}{$(\mathrm{mg} / \mathrm{gFW})$} & & & & \\
\hline $\mathrm{CON}^{1)}$ & - & - & - & - & $\begin{array}{c}7.04 \\
\pm 0.77^{\mathrm{c}}\end{array}$ & $\begin{array}{c}979.55 \\
\pm 226.58^{\mathrm{c}}\end{array}$ & $\begin{array}{l}1,760.00 \\
\pm 35.00^{\mathrm{c}}\end{array}$ & $27.83^{d}$ \\
\hline $\mathrm{CGS}^{2)}$ & $\begin{array}{c}22.51 \\
\pm 0.29^{6) \mathrm{a}}\end{array}$ & $\begin{array}{l}13.22 \\
\pm 2.20^{\mathrm{b}}\end{array}$ & $\begin{array}{l}35.81 \\
\pm 2.32^{\mathrm{b}}\end{array}$ & $\begin{array}{c}4.78 \\
\pm 0.08^{\mathrm{a}}\end{array}$ & $\begin{array}{c}8.65 \\
\pm 0.27^{\mathrm{c}}\end{array}$ & $\begin{array}{l}2,126.21 \\
\pm 285.66^{b}\end{array}$ & $\begin{array}{l}4,911.67 \\
\pm 300.22^{\mathrm{b}}\end{array}$ & $51.83^{\mathrm{c}}$ \\
\hline $\mathrm{TGS}^{3)} 1$ & $\begin{array}{r}19.31 \\
\pm 0.23^{b}\end{array}$ & $\begin{array}{c}7.17 \\
\pm 0.17^{\mathrm{c}}\end{array}$ & $\begin{array}{l}26.53 \\
\pm 0.31^{\mathrm{c}}\end{array}$ & $\begin{array}{c}4.71 \\
\pm 0.01^{\mathrm{a}}\end{array}$ & $\begin{array}{l}8.67 \\
\pm 0.01^{\mathrm{c}}\end{array}$ & $\begin{array}{l}2,036.82 \\
\pm 512.96^{\mathrm{b}}\end{array}$ & $\begin{array}{l}5,378.33 \\
\pm 166.00^{\mathrm{b}}\end{array}$ & $56.57^{\mathrm{b}}$ \\
\hline TGS2 & $\begin{array}{l}20.12 \\
\pm 0.59^{\mathrm{b}}\end{array}$ & $\begin{array}{c}8.81 \\
\pm 1.64^{\mathrm{c}}\end{array}$ & $\begin{array}{l}29.00 \\
\pm 1.16^{\mathrm{c}}\end{array}$ & $\begin{array}{c}4.84 \\
\pm 0.06^{\mathrm{a}}\end{array}$ & $\begin{array}{l}8.19 \\
\pm 0.69^{\mathrm{c}}\end{array}$ & $\begin{array}{l}2,130.46 \\
\pm 321.96^{\mathrm{b}}\end{array}$ & $\begin{array}{l}5,315.00 \\
\pm 115.33^{\mathrm{b}}\end{array}$ & $55.10^{\mathrm{b}}$ \\
\hline TGS3 & $\begin{array}{l}19.37 \\
\pm 0.61^{b}\end{array}$ & $\begin{array}{c}8.51 \\
\pm 1.20^{\mathrm{c}}\end{array}$ & $\begin{array}{l}27.94 \\
\pm 1.80^{\mathrm{c}}\end{array}$ & $\begin{array}{c}5.01 \\
\pm 0.70^{\mathrm{a}}\end{array}$ & $\begin{array}{l}11.68 \\
\pm 3.83^{\mathrm{b}}\end{array}$ & $\begin{array}{l}2,219.09 \\
\pm 400.83^{\mathrm{b}}\end{array}$ & $\begin{array}{l}5,416.66 \\
\pm 29.30^{\mathrm{b}}\end{array}$ & $56.50^{\mathrm{b}}$ \\
\hline TGS4 & $\begin{array}{l}22.95 \\
\pm 0.72^{\mathrm{a}}\end{array}$ & $\begin{array}{l}18.28 \\
\pm 1.73^{\mathrm{a}}\end{array}$ & $\begin{array}{l}41.32 \\
\pm 1.01^{\mathrm{a}}\end{array}$ & $\begin{array}{l}3.65 \\
\pm 0.52^{\mathrm{b}}\end{array}$ & $\begin{array}{l}16.75 \\
\pm 0.01^{\mathrm{a}}\end{array}$ & $\begin{array}{l}3,011.36 \\
\pm 97.24^{\mathrm{a}}\end{array}$ & $\begin{array}{l}8,703.33 \\
\pm 929.57^{\mathrm{a}}\end{array}$ & $68.06^{\mathrm{a}}$ \\
\hline F-value & $33.466^{* * *}$ & $26.116^{* * *}$ & $53.036^{* * *}$ & $5.798^{*}$ & $14.573^{* * *}$ & $11.309^{* * *}$ & $87.613^{* * *}$ & $471.680^{* * *}$ \\
\hline
\end{tabular}

${ }^{1)} \mathrm{CON}$, initial ginseng seed.

${ }^{2)}$ CGS, control ginseng sprout.

${ }^{3)}$ TGS, treated ginseng sprout.

${ }^{4)} \mathrm{GAE}$, gallic acid equivalent.

${ }^{5)} \mathrm{CHE},(+)$-catechin hydrate equivalent.

${ }^{6}$ Values $\underset{* * *}{a r}$ mean \pm SD. Different letters within a column are significantly different $(\mathrm{p}<0.05)$.

${ }^{*} \mathrm{p}<0.05,{ }^{* * *} \mathrm{p}<0.000$.

한 광량 및 처리시간이 있다고 판단된다.

\section{조사포닌 함량}

조사포닌 함량은 Table 3 과 같다. 초기 종자삼 $(\mathrm{CON})$ 사포 닌 함량에 비해 대조구(CGS) 및 처리구(TGS)에서 사포닌 함 량이 유의적으로 $(\mathrm{p}<0.05)$ 증가하였다. 21일차 생육한 CGS의 사포닌 함량은 $22.87 \%$ 증가한 반면에 플라즈마 방전수 처리 및 발효 양액(NO) 공급한 처리구 TGS3, TGS4에서는 각각 $65.91 \%, 137.93 \%$ 로 높은 증가율을 보였다. Noh 등(2020)에 따르면 담액수경재시 상추에 플라즈마 활성수 처리는 뿌리부 분의 페놀류와 같은 이차 대사산물 및 기능성 물질 함량 증대 시켰다고 보고하여 $\mathrm{NO}_{3}$-가 다량 함유된 $\mathrm{NO}$ 양액 공급이 식 물 내 질소 축적으로 기능성 물질에 증가에 영향을 준 것으로 판단된다. 또한, TGS4가 다른 처리구에 비해 유의적으로 $(\mathrm{p}<0.05)$ 높게 나타났는데, 이는 Fournier 등(2003)의 연구에 따르면 Panax quinquefolius의 임간재배에서 광량을 높게 증 가시켰을 때 총 사포닌의 함량은 계속 증가하였으며, 적색광 원 조사 시 사포닌 함량을 증가시켰다는 결과로 보아 TGS4 가 광원에 노출되는 시간이 쌓여 광량 및 적색광원의 영향으 로 총 사포닌의 함량이 증가된 것으로 보이며, Kim 등(2009) 의 연구결과와 같은 경향을 보여 추후 광원 및 조사시간에
대한 연구가 필요하다고 판단된다.

\section{총폴리페놀 및 플라보노이드 함량}

새싹삼의 총폴리페놀 및 플라보노이드 함량은 Table 3과 같다. 처리구 TSG4에서 유의적으로 $(\mathrm{p}<0.05)$ 높은 값을 나타 냈다. 자연환경에서 스트레스에 노출된 식물은 세포막과 유 기체를 스스로 보호하기 위해 식물 스스로가 항산화 효소를 활성시킨다(Mittler 등, 2004)고 보고된 바로 광 노출시간이 긴 TSG4에서 항산화 물질이 많이 발생된 것으로 판단된다. 또한, 플라즈마 방전수를 처리한 처리구(TGS)에서 폴리페놀 과 플라보노이드 함량이 높은 경향이 나타났는데, 이는 Noh 등(2020)에 따르면 플라즈마 활성수 생성 시 만들어진 RNS 중에서 $\mathrm{NO}_{3}{ }^{-}$는 식물체의 뿌리에 있어서 질소 $(\mathrm{N})$ 의 공급원이 되어 상추의 페놀산 및 플라보노이드의 생합성에 관여한다고 하였으며, 플라즈마 활성수가 직접 접촉되는 뿌리 부분 경우 모든 페놀류가 높게 나타나, 뿌리채소의 수경재배 방식에 적 용 시 기능성 물질 증대할 수 있다고 보고하였다. 뿐만 아니라 적정량의 질소 공급은 phenolic acid, flavonoids, ascorbic acid를 증가시켰다는 결과(Mampholo, 2018)로 $\mathrm{NO}_{3}$ 가 다량 함유된 발효 양액(NO) 공급이 처리구 TSG1, TSG3 및 TSG4 의 생육 중에 항산화 물질 증대에 영향을 준 것으로 판단된다. 


\section{ABTS 라디컬 소거능}

새싹삼의 ABTS 항산화능(\%)은 Table 3과 같다. ABTS 라 디칼 소거능 $(5,000 \mu \mathrm{g} \mathrm{L}$-ascorbic acid/g sample)은 종자삼 $(\mathrm{CON})$ 은 $27.85 \%$ 이며, 대조구 $(\mathrm{CGS})$ 는 $51.83 \%$ 로 나타났고, 처리구 $\mathrm{TGS} 1$ 은 $56.57 \%, \mathrm{TSG} 2$ 는 $55.1 \%, \mathrm{TSG} 3$ 는 $56.5 \%$ 그 리고 TGS4가 68.06\%로 나타나 다른 처리구보다 TGS4가 유 의적으로 $(\mathrm{p}<0.05)$ 높게 나타났다. 이는 조사포닌 및 폴리페 놀, 플라보노이드 결과와 비슷한 경향으로 나타났다.

\section{요 약}

본 연구는 LED처리 및 플라즈마 방전수 영향이 담수경 재 배에서 새싹삼의 생육 및 품질에 미치는 영향을 분석하고자 하였다. 스마트 팜 내에서 담수경 재배하였고, 새쌈삼은 1년 근 종자삼을 사용하였다. 대조구(CGS)에는 청색광이 주된 $\mathrm{LED}$ 를 처리하고, 처리구(TGS)에는 청색광+적생광 혼합 식 물용 $\mathrm{LED}$ 를 처리하였다. 조사시간은 $\mathrm{CGS}$ 과 $\mathrm{TGS1}$, TGS2, $\mathrm{TGS3}$ 에는 $9 \mathrm{~h}(9-18)$ 를, TGS4에는 $24 \mathrm{~h}$ 를 조사하였다. 플라 즈마 방전수는 CGS와 TGS1을 제외한 처리구에 재배수로 사용하였다. 양액은 CGS에는 처리하지 않고 TGS1, TGS3, TGS4에는 발효양액(NO)을, TGS2에는 소수화 미네랄 양액 $(\mathrm{HW})$ 를 공급하였다. 새싹삼은 7-14일차에서 24시간 조사한 TGS4에서 전체 길이나 초장 길이에서 높은 증가율을 보였고, 21일차에는 NO 양액을 처리한 TGS1, TGS3, TGS4가 초장 길이, 엽수 등 생장이 우수하였다. 총 부패율(\%)은 TGS1, $\mathrm{TGS} 2$ 및 TGS3가 4.24-4.65\%로 CGS와 TGS4에 비해 낮게 나타났다. 엽록소 $\mathrm{a}, \mathrm{b}$ 및 총엽록소 함량이 TGS4가 유의적으 로 $(\mathrm{p}<0.05)$ 높게 측정되었으나, 총카로티노이드 함량은 TGS3 가 높은 경향을 보였다. 또한, 조사포닌과 총폴리페놀 및 플 라보노이드 함량에서 $\mathrm{NO}$ 양액 및 플라즈마 방전수를 처리한 TGS3와 TGS4에서 높게 나타났고 특히, $24 \mathrm{~h}$ 조사한 TGS4 에서 유의적으로 $(\mathrm{p}<0.05)$ 높은 값을 보였다. $\mathrm{ABTS}$ 라디칼 소거능(\%)에서도 같은 경향을 보였다. 따라서 새싹삼 담수경 재배 시 양액 설정 및 플라즈마 방전수가 생육에 영향을 미치 며, LED 조사시간이 생육뿐 아니라, 기능성 물질에 영향을 주는 것으로 보였다. 본 연구결과, 담수경 재배 시 TGS4 조 건이 새싹삼 생장 및 조사포닌, 항산화 물질 등에는 높게 나 타나, 기능성 면에서는 우수하나 생육 중 부패율이 높은 것을 보아 추후 파장대 및 조사시간(명암주기)을 달리한 생육 연 구가 필요할 것으로 판단된다.

\section{감사의 글}

본 연구는 전라북도 혁신성장 R\&D+사업(RA 201905-03-
C4)의 지원 및 산업통상자원부와 한국산업기술진흥원의 지 역혁신클러스터육성사업(P0004795)으로 수행된 연구결과입 니다.

\section{Conflict of interests}

The authors declare no potential conflict of interest.

\section{ORCID}

Seo-Young Jeon https://orcid.org/0000-0002-1703-8932 Ki-Hyun Kwon https://orcid.org/0000-0002-1811-5434

\section{References}

Chang EH, Lee JH, Choi JW, Lim SY, Shin IS. Effects of storage temperature and film treatment on sprouting and growth of ginseng seedlings. Korean J Food Preserv, 27, 534-543 (2020)

Chee CK. The proceedings of the Korean institute of illuminating and electrical installation engineers. J Korean Inst IIIum Electr Install Eng, 15, 4-13 (2001)

Cho BH. Effect of the far infrared irradiated water on the growth of the cotyledons, hypocotyls and roots of the spring radishes. Anal Sci Technol, 22, 277-284 (2009)

Erwin JE, Heins RD, Moe R. Temperature and photoperiod effects on Fuchsia $\times$ hybrid morphology. J Amer Soc Hort Sci, 116, 955-960 (1991)

Fournier AR, Proctor JT A, Gauthier L, Khanizadeh S, Belanger A, Gosselin A, Dorais M. Understory light and root ginsenosides in forest-grown Panax quinquefolius. Phytochemistry, 63, 777-782 (2003)

Health Functional Food Standards and Standards (Notification No. 2004-14). Ginseng/Red Samsung Powder Products. Ministry of Food and Drug Safety, Cheongju, Korea, p 47-54 (2004)

Kim MJ, Li XG, Han JS, Lee SE, Choi JE. Effect of blue and red LED irradiation on growth characteristics and saponin contents in Panax ginseng C. A. Meyer. Korean J Medi Crop Sci, 17, 187-191 (2019)

Kim SG, Bok GJ, Lee GI, Park JS. Growth characteristics of lettuce under different frequency of pulse lighting and RGB ratio of LEDs. J Bio Env Con, 26, 123-132 (2017) Lee JD, Park JA, Park BJ, Jeong CS, Park SY, Paek KY. 
Effect of shading, light quality and chemical elicitation on growth and bioactive compound content of Potentilla kleiniana Wight et Arnott. Korean J Plant Res, 29, 363-375 (2016)

Lee YR, Seo JH, Hong CY, Kim KH, Lee JS, Jeong HS. Antioxidant activities of hydropoic-cultured ginseng roots and leaves. Korean J Food Nutr, 33, 58-63 (2020)

Lichtenthaler HK. Chlorophylls and carotenoids: Pigments of photosynthetic biomembranes. Method Enzymol, 148, 350-382 (1987)

Mampholo BM, Maboko MM, Soundy P, Sivakumar D. Variety-specific responses of lettuce grown in a gravelfilm technique closed gydroponic system to $\mathrm{N}$ supply on yield, morphology, phytochemicals, mineral content and safety. J Integr Agric, 17, 2447-2457 (2018)

Ministry of Food and Drug Safety (MDFS). Standards and Specifications of Health Functional Foods. Ministry of Food and Drug Safety, Cheongju, Korea (2020)

Mittler R, Vanderauwera S, Gollery M, Van Breusegem F. Reactive oxygen gene network of plants. Trends Plant Sci, 9, 490-498 (2004)

Moreno MIN, Isla MI, Sampietro AR, Vattuone MA. Comparison of the free radical scavenging activity of propolis from several regions of Argentina. J EthnoPharmacol, 71, 109-114 (2000)

Noh SW, Park JS, Kim SJ, Kim DW, Kang WS. Effect of plasma-activated water process on the growth and functional substance content of lettuce during the cultivation period in a deep flow technique system. J Bio-Env Con, 29, 464-472 (2020)

Park JE, Park YG, Jeong BR, Hwang SJ. Growth and anthocyanin content of lettuce as affected by artificial light source and photoperiod in a closed-type plant production system. Kor J Hort Sci Technol, 30, 673-679 (2012)

Park SH, Park JY, Choe WH. Origin of hydroxyl radicals in a weakly ionized plasma-facing liquid. Chem Eng J, 378, 1-8 (2019)

Park SY, Nam BH, Kim JM, Choi KB, Yeon KS, Kim YS. Vegetation and water purification characteristics of lapilli-bio block. J Korean Soc Agric Eng, 58, 47-54 (2016)

Re R, Pellegrini N, Proteggente A, Pannala A, Yang M, Rice-Evans C. Antioxidant activity applying an improved
ABTS radical cation decolorization assay. Free Radic Biol Med, 26, 1231-1237 (1999)

Ryu JH, Kwon S, Shin JH, Hong YC. Improving seedling growth by microwave plasma activated-water. Paper presented at 104th Annual Spring Conference of the Korean Society For Horticultural Science, May 25, Changwon, Korea, p 83 (2016)

Ryu SM, Park HK, Lee BJ. Study on the characteristics of dielectric barrier discharging system and usability as a disinfectant. J Korean Soc Water Wastewater, 18, 529536 (2004)

Saebo A, Krekling T, Appelgren M. Light quality affects photosynthesis and leaf anatomy of birch plantlets in vitro. Plant Cell Tiss Organ Cult, 41, 177-185 (1995)

Seo SG, Gang SW, Beak JP, Kim SH, Park KW, Lee YB. Plant Factory. World Science, Seoul, Korea, p 10-28 (2008)

Seong BJ, Kim SI, Jee MG, Lee HC, Kwon AR, Kim HH, Won JY, Lee KS. Changes in growth, active ingredients, and rheological properties of greenhouse-cultivated ginseng sprout during its growth period. Korean J Medi Crop Sci, 27, 126-135 (2019)

Shin BK, Son JE, Choi JM. Impact of compositions and concentrations of fertilizer solution on growth of lettuce and changes in chemical properties of poot media. J Bio Env Con, 22, 193-201 (2013)

Singleton VL, Rossi JA. Colorimetry of total phenolics with phosphomolybdic-phosphotungstic acid reagents. Am J Enol Viticult, 16, 144-158 (1965)

Son KH, Park JH, Kim DI, Oh MM. Leaf shape index, growth, and phytochemicals in two leaf lettuce cultivars grown under monochromatic light-emitting diodes. Kor J Hort Sci Technol, 30, 664-672 (2012)

Yang DC, Choi HY, Kim YH, Yun KY, Yang DC. Effects of light on the pigment production and chloroplast development of ginseng hairy roots. Korean J Ginseng Sci, 21, 28-34 (1997)

Yi HJ, Choi JM, Jang SW, Jung SK. Influence of $\mathrm{NO}_{3^{-}}$: $\mathrm{NH}_{4+}$ ratios in fertilizer solution on growth and yield of hot pepper (Capsicum annuum L.) in pot cultivation. Kor J Hort Sci Technol, 31, 65-71 (2013)

Yoo SJ. Status of plasma technology applied to agriculture and foods. Vacuum Magazine, 2, 4-8 (2015) 